\title{
Information, Popular
} Constraint, and the Democratic Peace

\section{Faculty Research Working Paper Series}

\author{
Philip B. K. Potter
}

University of Michigan

Matthew A. Baum

Harvard Kennedy School

\section{March 2014}

RWP14-015

Visit the HKS Faculty Research Working Paper Series at:

http://web.hks.harvard.edu/publications

The views expressed in the HKS Faculty Research Working Paper Series are those of the author(s) and do not necessarily reflect those of the John F. Kennedy School of Government or of Harvard University. Faculty Research Working Papers have not undergone formal review and approval. Such papers are included in this series to elicit feedback and to encourage debate on important public policy challenges. Copyright belongs to the author(s). Papers may be downloaded for personal use only. 


\title{
Information, Popular Constraint, and the Democratic Peace
}

\author{
Philip B. K. Potter, University of Michigan \\ Matthew A. Baum, Harvard University
}

February 2014

Politicians and scholars have long argued that democracies are less prone to international conflict, at least with other democracies. However, while there is widespread acceptance of this "law" in international affairs, the theoretical mechanism that drives it remains opaque. We argue that the distinctive behavior of democracies arises from very specific features of their political institutions that can facilitate (or hinder) the transmission of information between leaders and the public. Specifically, popular constraint on executive action relies on robust partisan opposition that can blow the whistle on foreign policy failures, and media institutions that can effectively relay this information to the voting public. Crucially, not all democracies are alike when it comes to these institutions, meaning that the "democratic peace" may not actually apply equally to all. We find support for these propositions in time series, cross-sectional analyses of conflict initiation from 1965 to 2006. 
Democracy promotion has long been a staple of U.S. foreign policy. Woodrow Wilson famously declared that World War I was fought to "make the world safe for democracy." More than half a century later, President Bill Clinton's (1996) National Security Strategy of Engagement and Enlargement argued that promoting democracy was in the strategic interest of the United States because "democracies create free markets that offer economic opportunity, make for more reliable trading partners, and are far less likely to wage war on one another" [emphasis added]. During the G. W. Bush administration, however, the policy morphed from one of democracy promotion to democratization, culminating in its use as a rational for the 2003 invasion of Iraq. Indeed, key figures in the Bush administration, including National Security Advisor Condoleezza Rice, explicitly based their policies on academic work on the democratic peace.

This level of policy influence should have been a triumph for political science, but many international relations scholars objected to what they saw as a misapplication of the democratic peace finding. ${ }^{1}$ Among other things, the critics argued that the Bush administration conflated the effects of external imposition of new democracy with those of consolidated, indigenous institutions. Others cited research (Mansfield and Snyder 2007) suggesting that during the initial phases of democratization countries can actually become more aggressive and war-prone, not less so.

Specific critiques aside, this debate points to a deeper problem. Scholars arrived inductively at most of our knowledge about democratic behavior in foreign affairs. Consequently, those seeking to move forward in either academic or policy domains confront a

\footnotetext{
${ }^{1}$ Thirty-three of them went so far as to place a signed advertisement on the New York Times OpEd page (26 September 2002) voicing their objections. Peterson et al. (2005) empirically demonstrate a more general divergence between scholarly and popular opinion on Iraq.
} 
conspicuous shortage of compelling theoretical explanations for the empirical observation of a democratic peace.

By what mechanism then might democracy lead to more peaceful behavior? Doyle (1983) and those who have followed on his work often point to the Kantian notion that the norms and political values adopted by the citizens of democracies drive the process. Yet this process has proven difficult to pin down and measure. In contrast, we make an institutionally based argument, whereby democratically elected leaders are constrained from starting conflicts when electoral and media institutions support a vibrant political opposition that is audible to voters via widespread access to mass media. These forces combine to place meaningful constraints on the executive's foreign policy actions when they diverge from public preferences. Absent a vibrant opposition, information about foreign policy missteps will be unavailable to the media, and hence to citizens, who will therefore be in a poor position to punish the leader should the policy prove ill conceived. Absent widely accessible media, the extent and credibility of the opposition and media will matter little, as the public will fail to receive any messages that political elites might send. The implication is that without robust opposition and media democratic leaders are nearly as unconstrained as their autocratic counterparts.

In the sections that follow, we develop this theoretical mechanism in more detail and test the resulting hypotheses on a variety of conflict events data, finding broad evidence of a relationship between information generation and transmission on the one hand, and conflict behavior on the other. We conclude with implications for policy and future research.

\section{Information and Constraint}

The relationship between a democratic public and their elected leaders closely adheres to what Miller (2005) calls "Weber's asymmetry," which describes the difference in power and 
information between principal and agent: the principal holds authority but the agent - that is, the actor to whom the principal delegates the power necessary to implement the principal's preferences - has the informational advantage. As such, representative government creates a classic principal-agent problem, with elected official as the often-unruly agents of citizens.

The principal-agent dilemma between representative government and citizens is one of accountability. Elected officials must be held accountable for their actions and for the actions of their government, and citizens must use their voting power to keep good governments in place and to dismiss those that perform poorly. The asymmetry in information, however, makes it difficult for citizens to differentiate between officials who act with good strategy and intentions but are unlucky and those who are incompetent or have bad intentions but whose policies nonetheless produce fortuitous positive outcomes (Downs and Rocke 1994).

Information helps to alleviate this problem, and in our view is the key to popular constraint on foreign policy in democracies. When it flows freely among leaders, elites, and the public, the principal-agent problem inherent in representative governance is minimized. This argument draws on a longstanding thread in the principal-agent literature. Holmstrom (1979), for example, suggests that increased monitoring leads to increased information, which principals could use to control their agents. When it comes to foreign policy, however, monitoring is especially difficult due the substantial information asymmetries that are typically built into the institutions that govern foreign policy in democracies (Baum and Potter 2008), as well as the generally low state of popular attention to (and knowledge about) foreign policy (Holsti 2004). We argue that, working in tandem, two factors - extensive political opposition in the form of parties and widespread access to a free and robust media - improve monitoring and therefore contribute to democratic constraint on foreign policy. 


\section{Political Opposition as Whistleblowers}

Leaders, both democratic and autocratic, have clear incentives to hide their foreign policy actions when they fail or conflict with the public's preferences. Minimizing their capacity to do so requires heterogeneous and autonomous political elites with both independent access to foreign policy information and the incentive to reliably alert the public when leaders stray too far from their preferred policies. Opposition political parties are the most obvious candidates to fill this role in democracies. Hence, we argue that the larger the number of consequential opposition parties, the more efficient this mechanism likely becomes. ${ }^{2}$ In this sense signals from opposition parties are analogous to McCubbins and Schwartz's (1984) fire alarms as a means of ameliorating principal agent problems. ${ }^{3}$

Why is a single opposition party sometimes insufficient? Downs (1957) links the number of political parties to the nature of political debate, arguing that a smaller number of parties introduces pathologies, including ineffective government in the absence of consensus among voters and ambiguous platforms and positions. He further shows, via a spatial model, that as the number of parties increases, each party must compete over a smaller ideological space and do so through more concrete policy positions. The result is greater granularity in policy positions and

\footnotetext{
${ }^{2}$ Schultz (2001) also notes the central theoretical role for opposition parties in the audience cost story, but does not model it statistically. Also, see Ramsey (2004) for a formal model of the role of opposition in crisis bargaining.

${ }^{3}$ We rely on the McCubbins and Schwartz (1984) fire alarm analogy because it so clearly invokes the theoretical mechanism that we believe drives the importance of independent opposition. However, they describe fire alarms as something that principles actively set up in order to efficiently delegate to agents while e are agnostic on the extent to which this role for opposition in the foreign policy process is intentional or accidental.
} 
more robust opposition to the government. This, in turn, makes it more likely that elite discord will emerge when foreign policy becomes potentially controversial, and by extension that the public will engage with the process. Politicians in systems with fewer parties, in contrast, have greater incentives to offer more vague policy stances in order to appeal to the median voter, which in turn dampens the quality of the information in the system (Downs 1957).

Other authors have noted the potential role for opposition parties in in the democratic peace. Reiter and Tillman (2002) investigate whether the number of parties, by itself (i.e. without a conditional relationship with media access), decreases the incidence of conflict by increasing constraint on leadership (they find that it does not). Palmer, Regan, and London (2004) also find that the number of parties in a ruling coalition has no influence on likelihood of dispute initiation or escalation. However, Leblang and Chan (2003) find that proportional representation systems are less likely to fight wars than their majoritarian counterparts.

To an important extent, variation in the extent of opposition (and with it responsiveness) is an intentional consequence of institutional design. Scholars have long recognized, for example, that consensual systems feature more parties than majoritarian systems specifically because this facilitates responsiveness (Powell 2000; Lijphart 1999). ${ }^{4}$ In such systems, leaders frequently face the possibility of a no confidence vote in the legislature and the resulting loss of power at any time. A foreign policy failure presumably increases the likelihood of such an

\footnotetext{
${ }^{4}$ The linkage between electoral institutions and democratic responsiveness is, however, contested. For instance, some recent research finds an ambiguous (Wlezien and Soroka 2012) or inverse relationship between proportionality (e.g. Kunicova and Rose-Ackerman 2005; Belchior 2012; Tavits 2007) or extreme party fragmentation (Anderson 2000), on the one hand, and democratic responsiveness, on the other.
} 
occurrence, particularly if the executive sits atop a coalition. Consequently, leaders in multiparty systems may be more concerned about public opinion irrespective of the information environment. The implication is that the number of parties alone may drive all of these relationships. If so, once we have accounted for the party system we should find no independent or interactive effects of media access and institutions. As we shall see, we in fact do find consistent evidence of interactive effects throughout our empirical investigations. This strongly suggests that while a multiparty system may be necessary ingredient for successful democratic constraint, it is not sufficient. Rather, responsiveness emerges only when robust opposition combines with media institutions and access that effectively relay their messages to the public.

\section{Media Institutions and the Transmission of Information}

The traditional approach in the political science literature has been to treat the media as an accommodating conduit for leaders' messages (Bloch and Lehman-Wilzig 2002; Brody 2001). ${ }^{5}$ The most well known variant of this perspective holds that the media "index" their coverage to elite rhetoric in Washington (Bennett 1990; Bennett et al. 2006; Hallin 1986). The implication is that absent the intervention of opposition elites, rather than mitigating the information gap between leaders and the public, the media frequently exacerbate it.

Some research, however, suggests that the media may be more proactive than indexing theories suggest. For example, the political communication "gatekeeper" literature (Galtung and Ruge 1965; White 1950; Patterson 1998) shows how journalists filter elite rhetoric by determining the newsworthiness of stories, implying that what actually gets through to consumers is an unrepresentative sample of elite positions (see also Baum and Groeling 2010a,

\footnotetext{
${ }^{5}$ For an exception, see Baum \& Groeling (2010a).
} 
Groeling 2010). Additional research (Baum and Groeling 2010b) suggests that if a conflict drags on long enough, even heavily indexed media in low-party systems will tend to catch up and perform at least some semblance of a watchdog function. However, such pressure is likely to arise far more gradually in a two-party relatively to a multiparty system, the latter of which will tend to feature earlier and more frequent challenges to the government.

Such caveats aside, the indexing hypothesis has proven durable in part because media $d o$ frequently transmit elite messages with largely intact frames. But what exactly are the media indexing to? Because much of the relevant literature was developed in the context of the United States where one party holds the presidency (the primary source of indexing) and a single party sits in opposition, scholars have given relatively little consideration to the role of differences in the extent of opposition. What work there is, however, indicates that the greater ideological diversity of multiparty systems tends to translate into more diverse media discussion, in terms of numbers of sources and frames - including challenges to the government's preferred frame - that a given outlet will cover (Baum 2013, Sheafer and Wolfsfeld 2009) and, as a consequence, a more politically knowledgeable and engaged citizenry (Moosbrugger n.d.; Benson 2009, Stromback and Dimitrova 2006, Pennings 1998, Powell 1982).

The higher quality information environment typically generated by the media of multiparty democracies leads to long-term advantages for the citizens of these states. Most notably, citizens exposed to a greater range of information thus operate on a day-to-day basis in a richer information environment that will tend to highlight a leader's foreign policy blunders. This leaves them better equipped to hold their leaders accountable, relative to citizens in two-party democracies.

Baum (2013) reports evidence consistent with these relationships. He finds that as the 
number of electoral parties in a state increases, media in that state offered relatively more policyoriented and less personality- or human interest-oriented news coverage of the Iraq War, as well as less support for governmental policy in Iraq and a wider range of frames in such coverage. More diversity in frames means more alternatives to the government's preferred frame, and, by extension the possibility of decreased support for it. This notion has some preexisting support in the extant comparative institutions literature. Shuck et al. (2011), for example, find that the extent of partisan contestation drives the relative salience of elections for the media, while Schuck et al. (2013) find that higher opposition systems tend toward more nuanced, policycentric coverage of elections. ${ }^{6}$

Of course, all these means little in the context of an unfree press where the executive can control what is or is not covered, and other scholars have noted the centrality of a free press to conflict processes. Van Belle (1997; 2000), for example, reports evidence that the presence of mutual free presses serves as an important institutional factor contributing to the near total absence of military conflict between pairs of democracies. ${ }^{7}$ Slantchev (2006) also argues that a non-strategic (that is, lacking partisan preferences), free media is a critical intervening variable, conditioning the value of opposition party criticism for helping citizens hold their leaders accountable for foreign policy decisions.

\footnotetext{
${ }^{6}$ Shi and Svensson (2006), for example, demonstrate that media access is associated with a decline in expropriation of public resources for private gain because it leads to an increase in the public's level of information about government performance. Along similar lines Besley, Burgess, and Prat (2002; see also Besley and Burgess 2001) show that media access can lead to an increase in governmental responsiveness to food shortages through much the same mechanism.

${ }^{7}$ James and Choi (2006) echo this finding, showing that mutual free presses are necessary to explain the democratic peace.
} 
However, this focus on press freedom as the primary link between the media and the democratic peace argument has had a practical downside for scholars seeking to unpack these hypothesized empirical relationships. Because democracy and media freedom are nearly perfectly collinear, any effects of media freedom are difficult to differentiate from the more prevalent arguments about regime type. Many autocracies have some of the institutional trappings of democracy, such as nominal "opposition" parties and rubber stamp legislatures. But few tolerate open dissent from the press corps. In contrast, there are few examples of heavily restricted media among established democracies outside wartime. The result is essentially perfect correspondence between dichotomous measures of democracy and press freedom. This left scholars with an interest in empirically testing the democratic peace proposition with little choice but to leave press freedom out of their models. This omission contributed to a broad blind spot among international relations scholars regarding the role of media, including the implications of variation in the capacity of democratic citizens to receive information transmitted via even the freest media ${ }^{8}$

The bottom line is that if citizens lack access to the media, they will inevitably have insufficient information with which to assess their leader's foreign policy activities. Even if there are opposition politicians interested in exposing the failure of an incumbent leader who have access to a free press inclined to transmit their critiques, absent broad public media access they will have a limited capacity to communicate with the public. In other words, if citizens lack

\footnotetext{
${ }^{8}$ Because our theory and empirical testing focuses on variations among democracies, we exclude press freedom from our core models. Nonetheless, as robustness checks we did run a series of models including press freedom as a control by relying on a measure of joint democracy to avoid the colinearity issue. As expected, they essentially replicate those reported below.
} 
access to the media and so cannot hear opposition critiques, the quality of transmitted information becomes largely irrelevant.

In contemporary mass democracies, where millions hold the franchise, the mass media are typically leaders' only vehicle for communicating broadly to citizens. This means that, all else equal, in countries where large proportions of the public have ready access to the press, citizens are more likely to be able to hear when their leaders call. Such leaders face greater potential risks from acting contrary to the preferences of their citizens, especially if they face an opposition likely to challenge their preferred foreign policy frame. They are thus, for better or worse, more constrained. The extent of public access to reliable political information via the media ought therefore to influence leaders' willingness to pursue potentially risky foreign policy actions. After all, if the public lacks access to the media, then many members of the public will lack sufficient credible information to evaluate a leader's foreign policy performance, at least in the short run (that is, until the longer-term consequences are apparent). ${ }^{9}$

\footnotetext{
${ }^{9}$ The primary concern raised by considering media access as a crucial intervening variable is that it might simply be measuring nations' levels of economic development, and this is driving the relationship with conflict. We have three responses to this concern. First, development and media access do not move in lockstep. For example, in 2003, Botswana's per capita GDP of $\$ 5,221$ was extremely similar to Lithuania's $\$ 5,360$ per capita. Yet television access in Lithuania was more than eleven times higher than in Botswana: 500 televisions per 1,000 people, compared to 44 in Botswana. Similarly, also in 2003, Iceland and the United States had nearly identical per capita GDPs of $\$ 37,700$ and $\$ 37,600$, respectively. Yet the United States had two-and-a-half times more TV's per 1,000 residents: 882 vs. 350 for Iceland. This brings us to our second retort, which is that we can in large part address such concerns by including basic measures of development in our empirical analyses. Admittedly, a skeptic might assert that the apparent relationship between access and responsiveness is still simply the result of residual correlation. But to this critique we offer our third reply, which is simply that we can think of no theoretically
} 


\section{Hypotheses}

The implication of the arguments that we have made thus far is that constraint on foreign policy does not arise automatically in democracies and in fact is elusive and fragile. Opposition without effective information transmission through the media will do little to narrow the information gap between elected officials and their citizen principals. Transmission without opposition is no better. One needs both the generation and transmission of information for the system to work. In other words, the fire alarm must sound and citizens must hear it before democracies are likely to behave in a meaningfully different way from autocracies in the realm of foreign policy.

Viewed in this light, it is unsurprising that a muddled picture of democratic distinctiveness in the realm of foreign policy emerges from the literature. While there are certainly mechanisms by which democracies can resolve their informational problems, they are by no means automatic and actually vary a great deal among democracies. The failure to model this heterogeneity (most often by modeling states dichotomously, as either democratic or autocratic) has led to ambiguous findings because leaders who are relatively constrained are lumped together with those who are not.

Previous studies have proffered arguments about the independent effects of opposition parties (e.g., Reiter \& Tillman 2002, Palmer et al. 2004, Leblang and Chan 2003) and media institutions (e.g., Shi and Svensson 2006, Besley, et al. 2002, Besley and Burgess 2001) on

satisfying reason why wealth, independent of its relationship with the variables we identify, should causally influence responsiveness. Moreover, even if it does so, it is unclear why such influence would move in opposing directions - as we will argue is the case with media access depending on whether the state has a two- or multi-party electoral system. 
democratic constraint in the contexts of war and provision of public goods. However, we anticipate the full constraining effect only when both conditions are present. In other words, information generation only matters if that information is successfully transmitted to citizens. Transmission to citizens, in turn, can only succeed in producing democratic constraint if the necessary information is available for transmitting. In fact, when partisan opposition is low, increased media access is more likely to facilitate rally effects that favor independent executive action than introduce constraint. This leads to our two hypotheses:

H1: Conditional Low-Access Initiation Hypothesis - Among democracies, at lower levels of public media access in the initiator state, variation in the number of parties will not significantly affect the likelihood of conflict initiation.

H2: Conditional High-Access Initiation Hypothesis - Among democracies, at higher levels of public media access in the initiator state, high opposition states will initiate fewer conflicts than low opposition states.

\section{Research Design}

Following standard practice in this literature, our unit of analysis is the "directed dyad" or pair of states. ${ }^{10}$ We explore a period spanning $1965-2006$. This period of analysis is substantially shorter than those generally employed in the democratic peace literature, which often to reach back to the $19^{\text {th }}$ century. This truncation, however, is necessary for incorporating the media element of our argument. Specifically, we constrain the period of analysis to correspond with the television age because access to television serves as one of our primary measures of media access.

To establish robust empirical support for our theory, we assess multiple measures of conflict. We first adapt the MID 4.0 data into a dyadic format, by coding our dependent variable

\footnotetext{
${ }^{10}$ In keeping with recent work in this area we include all dyads in the analysis. However, the findings hold when the sample is limited to politically relevant dyads.
} 
"1" when "state a" initiates a new MID against "state b" in the directed dyad in a given year and "0" otherwise. As a stricter test of the relationship with militarized disputes, we restrict some models to disputes entailing at least one battle-related casualty (so-called fatal MIDs). Since the vast majority of MIDs involve no violence at all, it is worth establishing whether the findings hold at this threshold or are driven by the less consequential MIDs. As a further test we replicate the analysis with the International Crisis Behavior (ICB) data set, employing international crises in place of MIDs as the unit of analysis.

We operationalize the extent of political opposition in two ways. We begin with the Effective Number of Parliamentary Parties (ENPP). ${ }^{11}$ This indicator weights each party by its seat share in the legislature and, as a result, excludes any parties that fail to win seats regardless of their overall activity or share of the vote. To further establish the robustness of our findings, we replicate our findings using the expected number of electoral parties (ENEP). ${ }^{12}$ This latter indicator is based on the total number of parties in the electoral system, weighted by their vote share, and thus includes those that do not win enough votes to gain seats in the legislature. ${ }^{13}$

In order to include non-democracies in the analysis, which is necessary in order to engage

${ }^{11}$ Golder (2005) defines ENPP based on the following formula, from Laakso and Taagepera (1979): $\frac{1}{\Sigma s_{i}^{2}}$ where $s_{i}$ is the percentage of seats won by the ith party, with independents or "others" coded as a single party

${ }^{12}$ Golder (2005) defines ENEP, in turn, with the following formula, which like the measure of ENPP is taken from Laakso and Taagepera (1979): $\frac{1}{\Sigma v_{i}^{2}}$ where $v_{i}$ is the percentage of votes won by the ith party (as opposed to the seat share).

${ }^{13}$ ENPP and ENEP correlate at.86. The distinction between them arises primarily because some parties fail to win sufficient numbers of votes to gain legislative seats. In general, we consider ENPP to be the better measure for our purpose because it captures the number of parties actually serving in the legislature and therefore in the best position to check the executive. 
with existing work on the democratic peace, we assume that there is just one "effective political party" in these states. However, since we are primarily concerned with distinctions within democracies (rather than between democracies and autocracies) we primarily assess variation in the relative values of opposition and access among democracies, thereby minimizing the impact of this assumption.

We also operationalize media access in multiple ways. The simplest is the number of televisions per 1,000 people. We focus on television access for two reasons, one conceptual and one practical. Beginning with the latter, far more (and more reliable) data are available on TV access than for other indicators of mass media. More significantly, however, television has been and remains by far the most important form of media worldwide for presenting political information to mass audiences. ${ }^{14}$

Nevertheless, to broaden the analysis we also explore a combined measure of TV \& Radio Access, which we arrive at by calculating the sum of televisions per 1000 people (normalized to a $0-1$ scale) and radios per 1,000 people (also normalized to a 0-1 scale). This measure allows us to address the uneven development among the countries in our analysis and is particularly helpful in the early years of our data set, when relatively fewer citizens in developing nations had access to television, even as radios were far more prevalent.

\footnotetext{
${ }^{14}$ According to a 2009 Pew Center survey of 25 countries - spanning nearly every region of the globe and level of economic development - an average of $72 \%$ of respondents named television as their primary source of news about national and international affairs. Newspapers came in second at less than $10 \%$, while the Internet took fourth place on the list, at $7.9 \%$. It is reasonable to anticipate that the dominance of television during much of our period of analysis was at least as high, and likely much higher.
} 
Most of our period of analysis predates the emergence of the Internet as a major mechanism for mass communication. The Internet functions through quite different mechanisms than those we have described and is therefore arguably at least somewhat orthogonal to our story. ${ }^{15}$ More importantly, as we have noted, television remains by far the most important source of news and information about politics for the vast majority of the world's population, even in countries with extensive internet access. Nonetheless, we control for the percentage of the population with access to the Internet to address any residual concern. ${ }^{16}$

Because our argument about the interactive relationship between partisan opposition and media access only holds in democratic states, we assess the three-way interaction between our two key explanatory variables (party opposition and media access) and regime type. In this way we can establish whether the mechanism that we identify functions in democracies, but not in autocracies (this distinction being a secondary implication of our theory). To accomplish this we include a continuous measure of regime type derived from the Polity IV project in our interaction terms.

There are a number of additional confounding factors that are likely correlated with both the explanatory variables we have just outlined and the incidence of conflict. As such, we must

${ }^{15}$ That said, recent research (Zuckerman 2013) finds that, at least among the more economically advanced countries, the overwhelming majority of Internet consumption (over 95\% on average) is domestically sourced. People may have access to news sources from around the world. Yet they overwhelmingly prefer domestic sources. This suggests that in critical respects the dynamics of Internet consumption, as regards our theory, likely resemble those for other media sources, like TV and radio.

${ }^{16}$ As an additional check, we added Internet usage to a combined media measure (which also contains radio and television access) and find the same patterns that we report in the models that follow. 
account for them or they could potentially bias our findings and undermine any conclusions that we might draw from them.

Numerous scholars have argued that power differentials between adversaries influence the emergence of conflict, but the precise nature of this relationship remains the subject of considerable debate. Some scholars see conflict as most likely under situations of relative power parity, or during power transitions (Organski 1958; Tammen 2000; Organski and Kugler 1977), Others see view a strong preponderance of power or declining power as more likely to motivate conflict (Levy 1987). For purposes of this study we are agnostic on these questions. But we nonetheless control for the initiators relative share of total capabilities within the dyad, utilizing data adapted from the National Material Capabilities (NMC) dataset. ${ }^{17}$

As with capabilities, there are numerous contradictory arguments about the implications of a standing alliance in a relationship between two states. The orthodox view (e.g., Singer 1966) is that allies are less likely to fight each other. Yet others (e.g., Bueno de Mesquita and Lalman 1988) have countered that alliances sometimes provoke international violence. Regardless, all of these authors share the view that standing alliance are correlated in one way or another with conflict. We thus account for the alliance portfolio similarity of the states in the dyad.

Major powers are, by definition, states with significant capabilities and wide-ranging interests in the international system. It follows that dyads containing at least one major power are likely to differ in their conflict behavior in important ways from those that do not. We thus account for the presence in a dyad of any of the five states coded by the Correlates of War

${ }^{17}$ The NMC dataset contains annual values for total population, urban population, iron and steel production, energy consumption, military personnel, and military expenditures (Singer 1987, 1972). 
project as major powers during our period of analysis: the US, UK, USSR/Russia, China, or France. $^{18}$

The literature has widely defined the relationship between trade and conflict as a key element of the "Kantian tripod", along with democracy and international organizations (Russett and Oneal 2001). Trade may also be related to the institutional variables we identify. To differentiate between these effects, we account for the ratio of bilateral trade and GDP. This captures the degree to which trade is important relative to the overall size of the economy.

For conflict to occur, states must have an issue of contention, but they must also be sufficiently geographically proximate (relative to their abilities to project power) for hostilities to actually take place. We thus control for the log of the capital-to-capital distance (in kilometers) between actors in a dyad. ${ }^{19}$ We also account for whether the states are contiguous (Gleditsch and Singer 1975; Henderson 1997; Schampel 1993). ${ }^{20}$

We include an additional control variable that is not typical in models of conflict initiation: child mortality. We do so to account for each country's relative level of development (Lake and Baum 2001). This variable reduces the likelihood that our media access variables will pick up any development effect that might then be collinear with media exposure, the object of our theoretical interest. This is important because some development research (e.g. Guo and Grummer-Strawn 1993; Montgomery et al. 2000) has employed our key indicator of media

18 This results in dummy variables assessing whether states in the dyad are major powers: Major/Major, Major/Minor, and Minor/Major. Minor/Minor is the reference category.

${ }^{19}$ We transform the variable to a logarithm to account for the rapid decay of the ability to project power and influence as distance increases.

${ }^{20} \mathrm{We}$ accomplish this with a six-category scale coded $1=$ land contiguity, $2=$ contiguous across up to 12 miles of water, $3=$ contiguous across 13-24 miles of water, $4=$ contiguous across 25-150 miles of water, $5=$ contiguous across $151-400$ miles of water, $6=$ not contiguous. 
access - television ownership - as a proxy for standard of living. At the same time, development may be associated with increased demands for political responsiveness and, through this mechanism, have a relationship with our dependent variable. We rely primarily on mortality because it has very complete data and is more sensitive to the bottom end of the income spectrum (which is where our concerns about development lie) than other available measures, such as GDP per capita. ${ }^{21}$

That said, for two reasons we also include per capita GDP of the potential initiator. First, doing so further controls for development and its relationship with media access. Second, scholars have attributed to economic development several, potentially contradictory, effects on conflict propensity. Some have argued that conflict is an increasingly inefficient way for rich states to obtain resources, relative to trade, enticement, and cooptation (Rosecrance 1986). At the other end of the spectrum, poor states may not be able to project power beyond their borders. Per capita GDP also accounts for these possibilities. $^{22}$

Another critical factor is simply the extent to which pairs of states have a history of fighting one another. The extensive body of work on enduring rivalries has shown that one of the best predictors of a state's involvement in a conflict with another state is a recent prior conflict

\footnotetext{
${ }^{21}$ We address remaining concerns about the relationship with development with the aforementioned measure that includes radio access, which is less subject to cross-national differences in development. More fundamentally, however, we can think of no clear logical argument for why "development" would influence conflict behavior in opposing manners depending on the number of parties in a given state. Absent such a logic, it is unclear how development could be driving the results we present here.

${ }^{22}$ Data comes from the World Bank.
} 
with the same state (Goertz and Diehl 1992). We follow Carter and Signorino's (2010) advice for dealing with this potential source of bias. ${ }^{23}$

\section{Findings}

Table 1 presents the coefficients and standard errors from five logistic maximum likelihood models on MID initiation.

Model 1 presents the bare bones specification that includes the key three-way interaction term and its constituent parts, but with no additional covariates. The consistency of these results with those from subsequent models demonstrates that the findings do not rely arise from the presence of the control variables. This parsimonious model also allows us to maintain the maximum available data, thereby bolstering confidence that the observed effect of group structure is not a function of bias generated by missing data in the covariates.

That said, as noted, numerous variables potentially correlate with both our independent and dependent variables and therefore should be accounted for if we are to avoid potential bias. Model 2 incorporates the basic controls found throughout most of the literature on the liberal peace. In Model 3 we then add the two controls for development (child mortality and GDP per capita) that we argue are necessary to address the potential ties between wealth and our indicators of media access.

${ }^{23}$ Specifically, this involves accounting for the number of peace years between observations of conflict and including set of cubic spline variables derived from that variable. Available evidence indicates that this solves the problem. The Durban-Watson $d$-statistic goes from approximately .2 without the correction to approximately 3, indicating no autocorrelation in the residuals. As an alternative, we also explored the corrections suggested Beck, Katz and Tucker (1998) and obtained nearly identical results. 
The problem of rare events is endemic to large, dyadic, time series, cross-sectional international conflict data sets. In other words, there is only a remote chance that there will be a conflict between any two states in a given year. In our data set, out of roughly 900,000 total dyad years, there were only 1,397 MID initiations (fatal MIDs and International Crises are even rarer). In other words, the likelihood of a use of force for between a randomly selected pair of states in a given year is extremely remote, less than one fifth of one percent. To address this issue, Model 4 presents a $\log \log$ model, which is specifically designed to correct for the bias introduced by rare positive occurrences. ${ }^{24}$

Models 5 and 6 replicate Model 3, but rely on alternative measures of our key concepts (opposition and access) to establish the robustness of the finding. Specifically, Model 5 operationalizes parties with Golder's measure of ENEP while Model 6 operationalizes access with our combined television and radio indicator.

\footnotetext{
${ }^{24}$ To some extent, our additional checks on politically relevant dyads, rather than all dyads, further assuages the rare events concern. We also obtain similar results when we employ Tomz, King, and Zeng's (1999) RELOGIT procedure.
} 
Table 1 - Models of Democratic Constraint and MID Initiation

\begin{tabular}{|c|c|c|c|c|c|c|}
\hline & $\begin{array}{l}\text { Model } 1 \\
\text { No Control } \\
\text { Variables } \\
\beta /(\mathrm{SE})\end{array}$ & $\begin{array}{l}\text { Model } 2 \\
\text { Traditional } \\
\text { Controls } \\
\beta /(\mathrm{SE})\end{array}$ & $\begin{array}{l}\text { Model } 3 \\
\text { Development } \\
\text { Controls } \\
\beta /(\mathrm{SE})\end{array}$ & $\begin{array}{l}\text { Model } 4 \\
\text { Log Log } \\
\text { Model } \\
\beta /(\mathrm{SE})\end{array}$ & $\begin{array}{l}\text { Model } 5 \\
\text { Alternate } \\
\text { Party Measure } \\
\beta /(\mathrm{SE})\end{array}$ & $\begin{array}{l}\text { Model } 6 \\
\text { Alternate Media } \\
\text { Measure } \\
\beta /(\mathrm{SE})\end{array}$ \\
\hline Parties & $\begin{array}{l}-0.263+ \\
(0.140)\end{array}$ & $\begin{array}{l}0.017 \\
(0.178)\end{array}$ & $\begin{array}{l}0.054 \\
(0.184)\end{array}$ & $\begin{array}{l}0.058 \\
(0.181)\end{array}$ & $\begin{array}{l}-0.080 \\
(0.124)\end{array}$ & $\begin{array}{l}0.155 \\
(0.235)\end{array}$ \\
\hline Media Access & $\begin{array}{l}-0.002 * * \\
(0.001)\end{array}$ & $\begin{array}{l}-0.001 \\
(0.002)\end{array}$ & $\begin{array}{l}-0.003 \\
(0.002)\end{array}$ & $\begin{array}{l}-0.003 \\
(0.002)\end{array}$ & $\begin{array}{l}-0.005^{*} \\
(0.002)\end{array}$ & $\begin{array}{l}-0.561 \\
(1.099)\end{array}$ \\
\hline Democracy & $\begin{array}{l}-0.081^{* * *} \\
(0.020)\end{array}$ & $\begin{array}{l}-0.045 \\
(0.029)\end{array}$ & $\begin{array}{l}-0.070 * \\
(0.031)\end{array}$ & $\begin{array}{l}-0.066^{*} \\
(0.030)\end{array}$ & $\begin{array}{l}-0.090 * * * \\
(0.026)\end{array}$ & $\begin{array}{l}-0.097^{* *} \\
(0.035)\end{array}$ \\
\hline Opposition*Democracy & $\begin{array}{l}0.018+ \\
(0.010)\end{array}$ & $\begin{array}{l}0.002 \\
(0.013)\end{array}$ & $\begin{array}{l}0.001 \\
(0.014)\end{array}$ & $\begin{array}{l}0.000 \\
(0.014)\end{array}$ & $\begin{array}{l}0.010 \\
(0.009)\end{array}$ & $\begin{array}{l}0.002 \\
(0.016)\end{array}$ \\
\hline Democracy*Access & $\begin{array}{l}0.000 * * * \\
(0.000)\end{array}$ & $\begin{array}{l}0.000+ \\
(0.000)\end{array}$ & $\begin{array}{l}0.000^{*} \\
(0.000)\end{array}$ & $\begin{array}{l}0.000^{*} \\
(0.000)\end{array}$ & $\begin{array}{l}0.000 * * * \\
(0.000)\end{array}$ & $\begin{array}{l}0.153^{*} \\
(0.072)\end{array}$ \\
\hline Opposition*Access & $\begin{array}{l}0.001 * * \\
(0.001)\end{array}$ & $\begin{array}{l}0.000 \\
(0.001)\end{array}$ & $\begin{array}{l}-0.001 \\
(0.001)\end{array}$ & $\begin{array}{l}-0.001 \\
(0.001)\end{array}$ & $\begin{array}{l}0.001 \\
(0.001)\end{array}$ & $\begin{array}{l}-0.770 \\
(0.818)\end{array}$ \\
\hline Opposition*Access*Democracy & $\begin{array}{l}-0.000^{* * *} \\
(0.000)\end{array}$ & $\begin{array}{l}-0.000 \\
(0.000)\end{array}$ & $\begin{array}{l}-0.000 \\
(0.000)\end{array}$ & $\begin{array}{l}-0.000 \\
(0.000)\end{array}$ & $\begin{array}{l}-0.000 \\
(0.000)\end{array}$ & $\begin{array}{l}0.009 \\
(0.048)\end{array}$ \\
\hline Capabilities & & $\begin{array}{l}1.159 * * * \\
(0.288)\end{array}$ & $\begin{array}{l}1.079 * * * \\
(0.288)\end{array}$ & $\begin{array}{l}1.084 * * * \\
(0.286)\end{array}$ & $\begin{array}{l}1.038^{* * *} \\
(0.292)\end{array}$ & $\begin{array}{l}0.828^{* *} \\
(0.282)\end{array}$ \\
\hline Trade & & $\begin{array}{l}0.039 * * * \\
(0.009)\end{array}$ & $\begin{array}{l}0.042 * * * \\
(0.009)\end{array}$ & $\begin{array}{l}0.039 * * * \\
(0.008)\end{array}$ & $\begin{array}{l}0.040 * * * \\
(0.009)\end{array}$ & $\begin{array}{l}0.041 * * * \\
(0.009)\end{array}$ \\
\hline Major/Major & & $\begin{array}{l}3.203 * * * \\
(0.510)\end{array}$ & $\begin{array}{l}3.120 * * * \\
(0.509)\end{array}$ & $\begin{array}{l}2.992 * * * \\
(0.475)\end{array}$ & $\begin{array}{l}3.256^{* * * *} \\
(0.449)\end{array}$ & $\begin{array}{l}2.662 * * * \\
(0.465)\end{array}$ \\
\hline Minor /Major & & $\begin{array}{l}1.467 * * * \\
(0.410)\end{array}$ & $\begin{array}{l}1.394 * * * \\
(0.406)\end{array}$ & $\begin{array}{l}1.369 * * * \\
(0.400)\end{array}$ & $\begin{array}{l}1.388^{* * * *} \\
(0.404)\end{array}$ & $\begin{array}{l}1.254 * * \\
(0.426)\end{array}$ \\
\hline Major/Minor & & $\begin{array}{l}1.243 * * * \\
(0.236)\end{array}$ & $\begin{array}{l}1.134 * * * \\
(0.230)\end{array}$ & $\begin{array}{l}1.082 * * * \\
(0.225)\end{array}$ & $\begin{array}{l}1.241^{* * *} \\
(0.224)\end{array}$ & $\begin{array}{l}1.058 * * * \\
(0.253)\end{array}$ \\
\hline Contiguous & & $\begin{array}{l}2.724 * * * \\
(0.267)\end{array}$ & $\begin{array}{l}2.769 * * * \\
(0.269)\end{array}$ & $\begin{array}{l}2.748 * * * \\
(0.260)\end{array}$ & $\begin{array}{l}2.708^{* * *} \\
(0.266)\end{array}$ & $\begin{array}{l}2.590 * * * \\
(0.279)\end{array}$ \\
\hline Distance & & $\begin{array}{l}-0.589 * * * \\
(0.098)\end{array}$ & $\begin{array}{l}-0.580 * * * \\
(0.100)\end{array}$ & $\begin{array}{l}-0.553 * * * \\
(0.092)\end{array}$ & $\begin{array}{l}-0.603 * * * \\
(0.103)\end{array}$ & $\begin{array}{l}-0.713 * * * \\
(0.100)\end{array}$ \\
\hline Alliance & & $\begin{array}{l}-0.161 * * \\
(0.054)\end{array}$ & $\begin{array}{l}-0.166 * * \\
(0.056)\end{array}$ & $\begin{array}{l}-0.156 * * \\
(0.053)\end{array}$ & $\begin{array}{l}-0.165 * * \\
(0.056)\end{array}$ & $\begin{array}{l}-0.206^{* * *} \\
(0.060)\end{array}$ \\
\hline Internet Access & & $\begin{array}{l}0.000 \\
(0.009)\end{array}$ & $\begin{array}{l}0.002 \\
(0.009)\end{array}$ & $\begin{array}{l}0.001 \\
(0.009)\end{array}$ & $\begin{array}{l}0.003 \\
(0.009)\end{array}$ & $\begin{array}{l}0.002 \\
(0.008)\end{array}$ \\
\hline Child Mortality & & & $\begin{array}{l}-0.005 * * \\
(0.002)\end{array}$ & $\begin{array}{l}-0.005 * * \\
(0.002)\end{array}$ & $\begin{array}{l}-0.005 * * \\
(0.002)\end{array}$ & $\begin{array}{l}-0.006 * * \\
(0.002)\end{array}$ \\
\hline GDPPC & & & $\begin{array}{l}-0.000 \\
(0.000)\end{array}$ & $\begin{array}{l}-0.000 \\
(0.000)\end{array}$ & $\begin{array}{l}-0.000+ \\
(0.000)\end{array}$ & $\begin{array}{l}-0.000 * * \\
(0.000)\end{array}$ \\
\hline $\mathrm{N}$ & 864,923 & 332,394 & 328,673 & 328,673 & 326,164 & 306,277 \\
\hline
\end{tabular}

$+p<0.10,{ }^{*} p<0.05,{ }^{*} p<0.01,{ }^{*} * * p<0.001$

Estimates for temporal dependence are supressed.Standard errors are clustered on the dyad.

It is worth noting that the key coefficients that relate to our hypotheses are relatively consistent across all model specifications. This is significant given the significant changes to the controls, dependent variables and modeling techniques across specifications. It suggests that while many of the controls do appear to influence states' conflict propensities, their relationships with the dependent variable are, in these data, largely distinct from those of our key independent 
variables. This suggests that the results from the fully specified models are unlikely to be artifacts of model specification.

Interpreting the substantive magnitudes of the effects of our key causal variables (media access and opposition) on the dependent variable (conflict initiation), however, is not intuitive in maximum likelihood models. Furthermore, the correct hypothesis test is not the difference between the coefficient estimates and zero, but rather whether variations across access and opposition are distinguishable from one another. Hence, the statistical significance or insignificance of the coefficients tells us little about the validity of our hypotheses.

To address these issues, we employ simulations to convert values for the organizational structure coefficient to predicted probabilities. This procedure makes it possible to investigate both the magnitude and statistical significance of the effects on the dependent variable caused by variations in the key causal variables in interaction with one another. In this instance, we assess the effects of increasing television access and media access from 0 to two standard deviations above the mean in high and low party states, while holding the control variables constant at their mean values. $^{25}$

The top left panel of Figure 1 shows our core finding for democracies. The top right panel demonstrates the same relationship (or, rather, the lack thereof) among autocracies. Both of the top panels are derived from Table 1, Model 3. The bottom row presents robustness checks for ENEP (from Table 1, Model 5) and the combined TV and Radio access indicator of media access (from Table 1, Model 6).

\footnotetext{
${ }^{25}$ For the simulations, we define low party states are those with two parties, while we define high party states as those with 5.5 (one standard deviation above the mean).
} 
Figure 1 - Democratic Constraint and MID Initiation
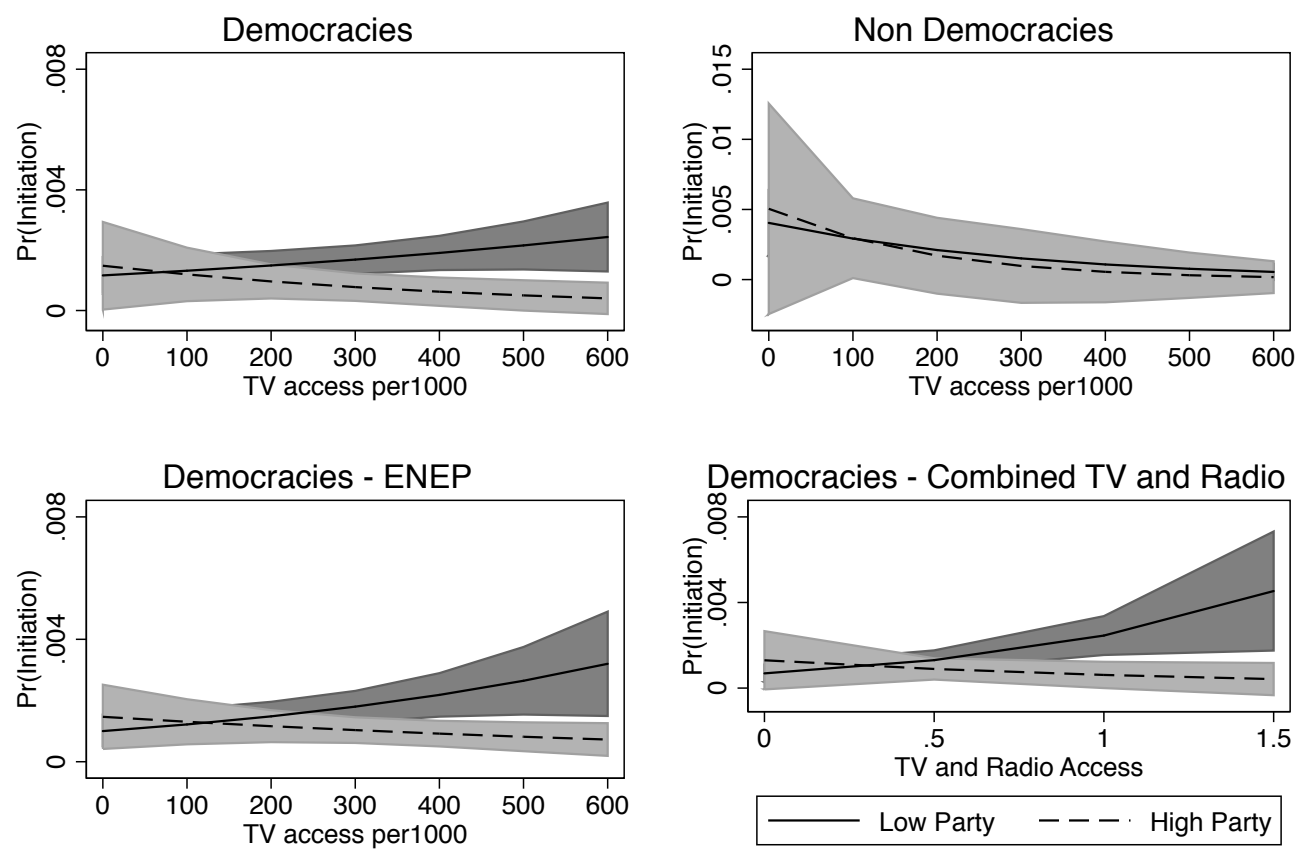

Several notable findings emerge from Figure 1. Foremost, as anticipated by our conditional hypotheses, among democracies (but not non-democracies), at higher levels of television or media access high-party (that is, high opposition) states are considerably less likely to initiate conflicts than are their low-party counterparts. The difference becomes statistically significant beginning at about 350 televisions per 1000 population (which is a bit less that a standard deviation above the global mean). For our combined TV and radio media access measure the distinction becomes statistically significant at about 0.75 , which is also approximately a standard deviation above the global mean.

Though the slopes are not always statistically significant, increased media access appears to be fairly consistently associated with reduced conflict initiation in high-party states, while the opposite pattern prevails in low-party states. The decrease among high-party states as access increases stems in a reasonably intuitive way from our theory. However, the rise among low party states might, on first glance, seem more puzzling. In our view, the likely explanation for 
this reversal is that a low level of opposition, in conjunction with a highly accessible press, is the perfect recipe for a substantial rally-round-the-flag effect (Mueller 1973; Brody 1991; Baum $2002) .^{26}$

More importantly for our hypothesis testing, there is a significant difference between the high- and low-party states in terms of the probability that they will initiate conflict when access is high. When access is low this distinction disappears. Comparing the top left panel with those on the bottom, it is clear that the findings are robust to either formulation of the party and media measures. As we have discussed, the robustness of this finding for the media measure resolves some concern over the extent to which development is driving the underlying findings.

\section{Alternative Measures of Conflict}

To determine the robustness of our findings across multiple indicators of conflict, we first assess the extent to which they hold in violent MIDs (that is, those involving fatalities). Other analysts (e.g. Downes and Sechser 2012) have complained that the MID dataset is littered with fishing disputes and minor border incursions that are neither politically important nor within the control of leaders, opposition, or the public. To partially address this we assess just fatal MIDs (with a binary dependent variable coded 1 for MIDs involving at least one fatality and zero otherwise). We expect that these are, all else equal, a higher salience subset of the broader class

${ }^{26}$ As we have noted, media in low party states are substantially more compliant with elite (and especially leadership) messaging than their brethren in higher party systems. Political opposition also tends to be disproportionately less robust, particularly in times of conflict or crisis. The result is the appearance of elite consensus around the leaders' foreign policy preferences, at least at the outset of conflict, and hence less constraint on the use of force. The large confidence interval around low party, high access, free press states stems from the small number of observations meeting this description. 
of MIDs. If our theory is accurate, insofar as it applies to conflict initiation, it should not be exclusively driven by lower-level non-violent events.

A still better robustness test would rely on an entirely distinct data collection effort for a measure of conflict initiation. For this, we turn to crisis data from ICB project (Brecher and BenYehuda 1985). ${ }^{27}$ Crises are presumably subject to the same theoretical relationship that we are interested in testing, but they are both conceptually distinct and immune to many of the specific critiques that scholars have lodged against the MIDs data (though they are certainly subject to their own critiques). The two data series correlate at just .27 in our data. The point is not that this is a superior measure to the MID data (or vice versa), but rather that the relative strengths and weaknesses of the two datasets are distinct and we should therefore be reassured if the proposed relationships emerge in both contexts.

Table 2 presents six models assessing the robustness of the findings to alternative dependent variables - fatal militarized interstate disputes and international crises. Models 1 and 2 explore each of these dependent variables with ENPP as the measure of partisan opposition. Models 3 and 4 replicate this for ENEP. Models 5 and 6 do the same for the previously introduced combined measure of television and radio access.

\footnotetext{
${ }^{27}$ We thus create a second dependent variable, coded 1 if "state A" initiates an international crisis for "state B" in a given year.
} 
Table 2 - Alternative Measures of Conflict Initiation

\begin{tabular}{|c|c|c|c|c|c|c|}
\hline & $\begin{array}{l}\text { Model } 1 \\
\text { Fatal MID } \\
\beta /(\mathrm{SE})\end{array}$ & $\begin{array}{l}\text { Model } 2 \\
\text { Crisis } \\
\beta /(\mathrm{SE})\end{array}$ & $\begin{array}{l}\text { Model } 3 \\
\text { Fatal MID } \\
\text { ENEP } \\
\beta /(\mathrm{SE})\end{array}$ & $\begin{array}{l}\text { Model } 4 \\
\text { Crisis } \\
\text { ENEP } \\
\beta /(\mathrm{SE})\end{array}$ & $\begin{array}{l}\text { Model } 5 \\
\text { Fatal MID } \\
\text { TV\&Radio } \\
\beta /(\mathrm{SE})\end{array}$ & $\begin{array}{l}\text { Model } 6 \\
\text { Crisis } \\
\text { TV\&Radio } \\
\beta /(\mathrm{SE})\end{array}$ \\
\hline Parties & $\begin{array}{l}0.034 \\
(0.325)\end{array}$ & $\begin{array}{l}0.025 \\
(0.427)\end{array}$ & $\begin{array}{l}-0.247 \\
(0.304)\end{array}$ & $\begin{array}{l}-0.936 \\
(0.586)\end{array}$ & $\begin{array}{l}0.162 \\
(0.347)\end{array}$ & $\begin{array}{l}0.045 \\
(0.504)\end{array}$ \\
\hline Media Access & $\begin{array}{l}-0.010 * * \\
(0.003)\end{array}$ & $\begin{array}{l}-0.008+ \\
(0.004)\end{array}$ & $\begin{array}{l}-0.012 * * \\
(0.004)\end{array}$ & $\begin{array}{l}-0.016^{* * *} \\
(0.005)\end{array}$ & $\begin{array}{l}-5.633^{* *} \\
(1.717)\end{array}$ & $\begin{array}{l}-3.801+ \\
(2.267)\end{array}$ \\
\hline Democracy & $\begin{array}{l}-0.143 * \\
(0.058)\end{array}$ & $\begin{array}{l}-0.060 \\
(0.062)\end{array}$ & $\begin{array}{l}-0.168 * * \\
(0.051)\end{array}$ & $\begin{array}{l}-0.129 * \\
(0.055)\end{array}$ & $\begin{array}{l}-0.184 * * \\
(0.067)\end{array}$ & $\begin{array}{l}-0.113 \\
(0.069)\end{array}$ \\
\hline Opposition*Democracy & $\begin{array}{l}0.024 \\
(0.023)\end{array}$ & $\begin{array}{l}0.021 \\
(0.029)\end{array}$ & $\begin{array}{l}0.036+ \\
(0.020)\end{array}$ & $\begin{array}{l}0.073+ \\
(0.038)\end{array}$ & $\begin{array}{l}0.023 \\
(0.025)\end{array}$ & $\begin{array}{l}0.027 \\
(0.035)\end{array}$ \\
\hline Democracy*Access & $\begin{array}{l}0.001 * * * \\
(0.000)\end{array}$ & $\begin{array}{l}0.001 * \\
(0.000)\end{array}$ & $\begin{array}{l}0.001 * * * \\
(0.000)\end{array}$ & $\begin{array}{l}0.001 * * * \\
(0.000)\end{array}$ & $\begin{array}{l}0.646 * * * \\
(0.124)\end{array}$ & $\begin{array}{l}0.415^{*} \\
(0.182)\end{array}$ \\
\hline Opposition*Access & $\begin{array}{l}0.003+ \\
(0.002)\end{array}$ & $\begin{array}{l}0.002 \\
(0.002)\end{array}$ & $\begin{array}{l}0.004 \\
(0.003)\end{array}$ & $\begin{array}{l}0.009 * * \\
(0.003)\end{array}$ & $\begin{array}{l}1.401+ \\
(0.848)\end{array}$ & $\begin{array}{l}0.883 \\
(0.948)\end{array}$ \\
\hline Opposition*Access*Democracy & $\begin{array}{l}-0.000 * \\
(0.000)\end{array}$ & $\begin{array}{l}-0.000+ \\
(0.000)\end{array}$ & $\begin{array}{l}-0.000 * \\
(0.000)\end{array}$ & $\begin{array}{l}-0.001^{* *} \\
(0.000)\end{array}$ & $\begin{array}{l}-0.184 * * \\
(0.069)\end{array}$ & $\begin{array}{l}-0.122 \\
(0.078)\end{array}$ \\
\hline Capabilities & $\begin{array}{l}0.553 \\
(0.545)\end{array}$ & $\begin{array}{l}0.941 \\
(0.664)\end{array}$ & $\begin{array}{l}0.525 \\
(0.560)\end{array}$ & $\begin{array}{l}0.934 \\
(0.653)\end{array}$ & $\begin{array}{l}0.450 \\
(0.573)\end{array}$ & $\begin{array}{l}0.357 \\
(0.649)\end{array}$ \\
\hline Trade & $\begin{array}{l}-0.774 \\
(0.827)\end{array}$ & $\begin{array}{l}-2.036+ \\
(1.062)\end{array}$ & $\begin{array}{l}-0.752 \\
(0.765)\end{array}$ & $\begin{array}{l}-1.891+ \\
(0.973)\end{array}$ & $\begin{array}{l}-0.911 \\
(0.901)\end{array}$ & $\begin{array}{l}-2.402 * \\
(1.089)\end{array}$ \\
\hline Major/Major & $\begin{array}{l}1.820+ \\
(1.017)\end{array}$ & $\begin{array}{l}1.672+ \\
(1.014)\end{array}$ & $\begin{array}{l}1.660 \\
(1.043)\end{array}$ & $\begin{array}{l}1.558 \\
(1.003)\end{array}$ & $\begin{array}{l}0.591 \\
(0.913)\end{array}$ & $\begin{array}{l}1.591 \\
(1.095)\end{array}$ \\
\hline Minor /Major & $\begin{array}{l}1.528+ \\
(0.800)\end{array}$ & $\begin{array}{l}1.734+ \\
(0.936)\end{array}$ & $\begin{array}{l}1.546+ \\
(0.805)\end{array}$ & $\begin{array}{l}1.809^{*} \\
(0.918)\end{array}$ & $\begin{array}{l}1.818^{*} \\
(0.818)\end{array}$ & $\begin{array}{l}1.709+ \\
(0.905)\end{array}$ \\
\hline Major/Minor & $\begin{array}{l}1.188^{*} \\
(0.471)\end{array}$ & $\begin{array}{l}2.044 * * * \\
(0.588)\end{array}$ & $\begin{array}{l}1.224^{*} \\
(0.500)\end{array}$ & $\begin{array}{l}2.057 * * * \\
(0.578)\end{array}$ & $\begin{array}{l}1.109 * \\
(0.565)\end{array}$ & $\begin{array}{l}2.155 * * * \\
(0.630)\end{array}$ \\
\hline Contiguous & $\begin{array}{l}4.176^{* * *} \\
(0.432)\end{array}$ & $\begin{array}{l}3.242 * * * \\
(0.603)\end{array}$ & $\begin{array}{l}4.075 * * * \\
(0.452)\end{array}$ & $\begin{array}{l}3.119 * * * \\
(0.595)\end{array}$ & $\begin{array}{l}4.333 * * * \\
(0.543)\end{array}$ & $\begin{array}{l}2.991 * * * \\
(0.675)\end{array}$ \\
\hline Distance & $\begin{array}{l}-0.370 * * * \\
(0.110)\end{array}$ & $\begin{array}{l}-0.509 * * \\
(0.159)\end{array}$ & $\begin{array}{l}-0.387 * * * \\
(0.113)\end{array}$ & $\begin{array}{l}-0.553^{* * *} \\
(0.159)\end{array}$ & $\begin{array}{l}-0.475 * \\
(0.186)\end{array}$ & $\begin{array}{l}-0.663 * * * \\
(0.200)\end{array}$ \\
\hline Alliance & $\begin{array}{l}-0.201+ \\
(0.121)\end{array}$ & $\begin{array}{l}0.017 \\
(0.099)\end{array}$ & $\begin{array}{l}-0.204+ \\
(0.123)\end{array}$ & $\begin{array}{l}0.011 \\
(0.103)\end{array}$ & $\begin{array}{l}-0.264+ \\
(0.145)\end{array}$ & $\begin{array}{l}-0.007 \\
(0.107)\end{array}$ \\
\hline Internet Access & $\begin{array}{l}-0.031 \\
(0.027)\end{array}$ & $\begin{array}{l}0.017 \\
(0.019)\end{array}$ & $\begin{array}{l}-0.025 \\
(0.025)\end{array}$ & $\begin{array}{l}0.021 \\
(0.019)\end{array}$ & $\begin{array}{l}-0.028 \\
(0.027)\end{array}$ & $\begin{array}{l}0.013 \\
(0.017)\end{array}$ \\
\hline Child Mortality & $\begin{array}{l}-0.003 \\
(0.002)\end{array}$ & $\begin{array}{l}0.002 \\
(0.003)\end{array}$ & $\begin{array}{l}-0.003 \\
(0.003)\end{array}$ & $\begin{array}{l}0.002 \\
(0.003)\end{array}$ & $\begin{array}{l}-0.006^{*} \\
(0.003)\end{array}$ & $\begin{array}{l}-0.000 \\
(0.003)\end{array}$ \\
\hline GDPPC & $\begin{array}{l}-0.000 \\
(0.000)\end{array}$ & $\begin{array}{l}0.000 \\
(0.000)\end{array}$ & $\begin{array}{l}-0.000 \\
(0.000)\end{array}$ & $\begin{array}{l}-0.000 \\
(0.000)\end{array}$ & $\begin{array}{l}-0.000+ \\
(0.000)\end{array}$ & $\begin{array}{l}-0.000 \\
(0.000)\end{array}$ \\
\hline $\mathrm{N}$ & 328,673 & 328,673 & 326,164 & 326,164 & 306,277 & 306,277 \\
\hline
\end{tabular}

$+p<0.10, * p<0.05, * * p<0.01, * * * p<0.001$

Estimates for temporal dependence are supressed.Standard errors are clustered on the dyad.

The key takeaway is the similarity between these findings and those derived from the

full MID dataset. However, a clearer picture emerges from the graphed predicted probabilities,

which, in Figure 2, we present for Models 1 and 2 of Table 2. 
Figure 2 - Alternative Measures of Conflict Initiation
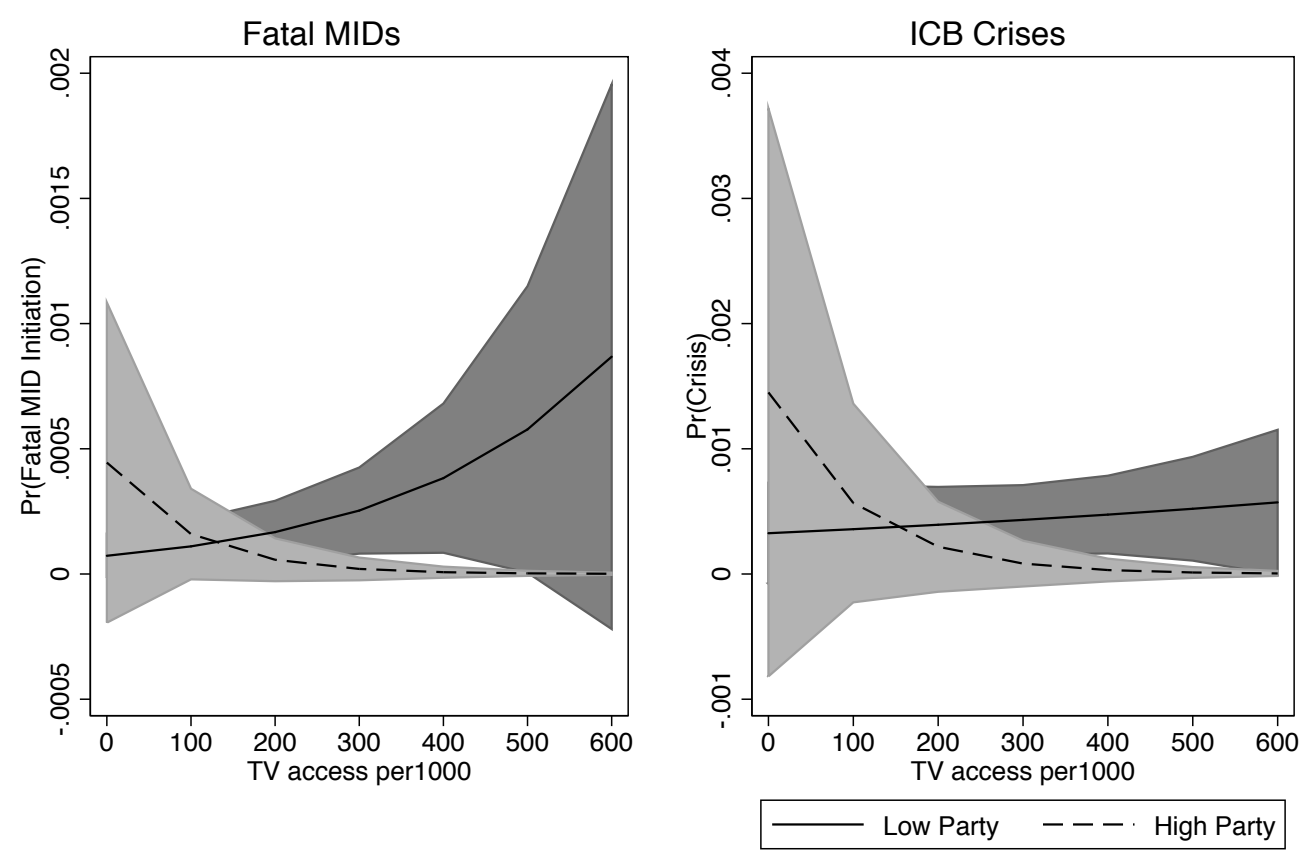

At higher levels of media access high opposition states are statistically significantly and substantially less likely to initiate both crises and fatal militarized disputes than are their low opposition counterparts. Notably, however, these findings are among the few that are not statically significant at traditional levels at points above a certain threshold. Instead, the distinction between low and high party systems emerges around 400 to 500 televisions per 1000 population, but then disappears again at higher levels where the data becomes too sparse (particularly for low party states). The lessened stability of the findings on crises and fatal MIDs is unsurprising given that these events are even more infrequent than the already relatively rare occurrences of MIDs. As a result, there is too little data at both the very low and very high ends of the media access measures.

\section{Conclusion}


Despite the voluminous literature on the democratic peace that suggests that democracies do not typically initiate conflicts against one another, precisely how this process works has remained largely opaque. The explanation for this dearth of theory about the underlying mechanism behind the democratic peace can be attributed in part to the origins of the recent literature on the subject. While scholars regularly trace the idea of a peace between democracies to Kant ([1795] 1983), the lineage of the current literature is actually more appropriately traced the to the echoes of the behavioral revolution that fundamentally shifted empirical research in international relations in the 1960s and 1970s. Drawing on the first broad datasets of international conflict, a number of scholars quickly observed the absence of conflict between democratic states in their statistical models (e.g. Rummel 1979; Babst 1972; Singer and Small 1972). However, this legacy has meant that the democratic peace has had difficulty progressing so much so that some have described it as an empirical regularity in search of an explanation (Ray 2000). Indeed, the mechanisms identified by this literature by and large consist of post-hoc explanations for empirical findings. In response, we have presented a more robust, deductive theory of democratic constraint and generated finding that specifically address the expectations that arise from it.

It is worth emphasizing that our findings indicate a monadic democratic peace (i.e. democracy with the attributes we identify fight less overall) rather than a dyadic peace (i.e. democracies do not fight each other). This is a substantial departure from the existing literature, which has generally only found empirical support for the more limited dyadic proposition. Given that we find support for our key predictions, this underlines the potential importance of these arguments for academics and policymakers alike. Once we recognize the diversity of democratic institutions we can easily reconcile the general dearth of evidence of uniquely pacific democratic 
conflict behavior at the monadic level with the recurrent finding of a dyadic democratic peace. More specifically, we find that robust political opposition and widespread access to the mass media can, in tandem, go a long way toward accounting for the longstanding empirical observation that democracies rarely go to war against one another

The conditional argument we present and test here suggest the need for more finely honed policies that move beyond a single-minded focus on democratization. Specifically, our findings indicate that those looking to institute executive constraint and the positive international externalities that come with it should be promoting specific institutional attributes rather than democracy in any form. This means a much more mundane promotion of robust media and electoral institutions. While such policies may be less dramatic than images of ink-stained thumbs raised in the air signifying a nation's first free election, they may prove more effective in producing the very pacific foreign policy behavior that democratic leaders - especially U.S. presidents - routinely cite as a primary justification for promoting democracy abroad.

Nonetheless, while policymakers rarely cite factors like the number of parties or media access in speeches about promoting democracy, when the proverbial rubber meets the road, they often advocate that new democracies choose consociational constitutions. A case in point is Iraq. While American leaders publicly focused on the "triumph" of free elections, they more quietly pushed Iraq to adopt a multi-party, consociational system. They did so not in anticipation of any additional pacifying effect on Iraqi foreign policy owing to multipartism (as per our argument here). Rather, they viewed consociationalism as necessary to create sufficient domestic political buy-in among the disparate stakeholders in Iraq. In other words, the United States advocated a multi-party system for Iraq's domestic political purposes. Yet our findings suggest that this choice may potentially produce an important unintended positive foreign policy externality. 
Nonetheless, U.S. advocacy of a multi-party system is perhaps surprising, and arguably ironic, since the United States is itself the archetypal two-party democracy. Such a system, if successfully institutionalized, could produce the very sort of robust political opposition that we argue underpins, along with mass access to media, the pacific behavior of some democracies. Of course, it remains an open question whether Iraq will successfully institutionalize its nascent democratic institutions. Regardless, our findings suggest an important, yet largely overlooked, mechanism through which the media and electoral institutions shape states' conflict behavior. That is, our findings suggest that the nature of a state's information generation and transmission mechanisms, in interaction, importantly influence democratic constraint. The implication is that not all democracies are alike, or equally likely to participate in any Kantian pacific federation. Only by recognizing the significant diversity of democratic institutions might the empirical observation of a democratic peace finally hope to meet its theoretical match. 


\section{References}

Anderson, Christopher. 2000. "Economic Voting and Political Context: A Comparative Perspective." Electoral Studies 19 (2):151-70.

Babst, D. V. 1972. "A force for peace." Ind. Res. 14 (55-58).

Baum, M. A. 2002. "The constituent foundations of the rally-round-the-flag phenomenon." International Studies Quarterly 46 (2):263-98.

Baum, M., and T.J. Groeling. 2010. War stories: The causes and consequences of public views of war. Princeton, NJ: Princeton University Press.

Beck, N., J. N. Katz, and R. Tucker. 1998. "Taking time seriously: Time-series-cross-section analysis with a binary dependent variable." American Journal of Political Science 42 (4):1260-88.

Belchior, Ana Maria. 2012. "Explaining Left-Right Party Congruence Across European Party Systems A Test of Micro-, Meso-, and Macro-Level Models." Comparative Political Studies 46 (3):352-86.

Bennett, W. L. 1990. "Toward a theory of press-state relations in the United States." Journal of Communication 40 (2):103-25.

Bennett, W. L., R. G. Lawrence, and S. Livingston. 2006. "None Dare Call It Torture: Indexing and the Limits of Press Independence in the Abu Ghraib Scandal." Journal of Communication 56 (3):467-85.

Besley, Timothy, and Robin Burgess. 2001. "Political agency, government responsiveness and the role of the media." European Economic Review 45 (4):629-40.

Besley, Timothy, Robin Burgess, and Andrea Prat. 2002. "Mass media and political accountability."

Bloch, Y., and S. Lehman-Wilzig. 2002. "An Exploritory Model of Media-Government Relations." In Media and Conflict, ed. E. Gilboa. New York: Transnational Publishers.

Brecher, M., and H. Ben-Yehuda. 1985. "System and Crisis in International Politics." Review of International Studies (11):17-36.

Brody, R. A. 1991. Assessing the President: The Media, Elite Opinion and Public Support. Stanford: Stanford University Press.

- 2001. Assessing the President: The Media, Elite Opinion, and Public Support: Stanford University Press.

Bueno de Mesquita, B., and D. Lalman. 1988. "Empirical Support for Systemic and Dyadic Explanations of International Conflict." World Politics 41 (1):1-20.

Carter, D.B., and C.S. Signorino. 2010. "Back to the future: Modeling time dependence in binary data." Political Analysis 18 (3):271-92.

Downes, Alexander B., and Todd S. Sechser. 2012. "The illusion of democratic credibility." International Organization 66 (03):457-89.

Downs, A. 1957. An Economic Theory of Democracy. New York: Harper.

Downs, G. W., and D. M. Rocke. 1994. "Conflict, Agency, and Gambling for Resurrection - the Principal-Agent Problem Goes to War." American Journal of Political Science 38 (2):362-80.

Doyle, Michael W. 1983. "Kant, Liberal Legacies, and Foreign Affairs, Part 2." Philosophy \& Public Affairs 12 (4):323-53.

Galtung, J., and M. H. Ruge. 1965. "The Structure of Foreign News." Journal of Peace Research 2 (1):64-91. 
Gleditsch, K. S. 2002. All International Politics is Local: The Diffusion of Conflict, Integration, and Democratization. Ann Arbor: University of Michigan Press.

Gleditsch, Nils Petter, and J. David Singer. 1975. Distance and International War, 1816-1965. Paper read at International Peace Research Association, Fifth General Conference, at Oslo, Norway.

Goertz, Gary, and Paul F. Diehl. 1992. Territorial Changes and International Conflict. London: Routledge.

Golder, M. 2005. "Democratic electoral systems around the world, 1946-2000." Electoral Studies 24 (1):103-21.

Guo, Guang, and Laurence M Grummer-Strawn. 1993. "Child mortality among twins in less developed countries." Population Studies 47 (3):495-510.

Hallin, D. C. 1986. The "Uncensored War". Berkeley: University of California Press.

Henderson, Errol A. . 1997. "Culture or Contiguity: Ethnic Conflict, the Similarity of States, and the Onset of War, 1820-1989 " Journal of Conflict Resolution 41 (5):649-68.

Holmstrom, Bengt. 1979. "Moral hazard and observability." The Bell Journal of Economics:7491.

James, P., and S. Chio. 2006. "Media Openness, Democracy and Militarized Interstate Disputes: An Empirical Analysis." British Journal of Political Science 37:23-46.

Kant, Immanuel. [1795] 1983. Perpetual Peace and Other Essays on Politics, History and Morals. Indianapolis: Hackett Publishing Company.

Kunicova, Jana, and Susan Rose-Ackerman. 2005. "Electoral rules and constitutional structures as constraints on corruption." British Journal of Political Science 35 (04):573-606.

Laakso, M., and R. Taagepera. 1979. "The Effective Number of Parties: A Measure with Application to West Europe." Comparative Political Studies 12 (1):3.

Lake, D. A., and M. A. Baum. 2001. "The Invisible Hand of Democracy: Political Control and the Provision of Public Services." Comparative Political Studies 34 (August):587-621.

Leblang, David, and Steve Chan. 2003. "Explaining Wars Fought by Established Democracies: Do Institutional Constraints Matter?" Political Research Quarterly 56 (4):385-400.

Levy, J. S. 1987. "Declining Power and the Preventive Motivation for War." World Politics 40 (1):82-107.

Lijphart, A. 1999. Patterns of democracy. New Haven: Yale University Press.

Mansfield, Edward D, and Jack L Snyder. 2007. "The Sequencing" Fallacy"." Journal of democracy 18 (3):5-10.

Maoz, Z., and B. Russett. 1993. "Normative and Structural Causes of Democratic Peace, 19461986." American Political Science Review 87 (3):624-38.

McCubbins, M. D., and T. Schwartz. 1984. "Congressional Oversight Overlooked - Police Patrols Versus Fire Alarms." American Journal of Political Science 28 (1):165-79.

Miller, Gary J. 2005. "The political evolution of principal-agent models." Annu. Rev. Polit. Sci. 8:203-25.

Montgomery, Mark R, Michele Gragnolati, Kathleen A Burke, and Edmundo Paredes. 2000.

"Measuring living standards with proxy variables." Demography 37 (2):155-74.

Mueller, J. E. 1973. War Presidents and Public Opinion. New York: Wiley.

Organski, A. F. 1958. World Politics. New York: Alfred A. Knopf.

Organski, A. F., and J. Kugler. 1977. "Costs of Major Wars - Phoenix Factor." American Political Science Review 71 (4):1347-66. 
Palmer, Glenn, Tamar London, and Patrick Regan. 2004. "What's Stopping You?: The Sources of Political Constraints on International Conflict Behavior in Parliamentary Democracies." International Interactions 30 (1):1-24.

Patterson, T. E. 1998. "Time and News: The Media's Limitations as an Instrument of Democracy." International Political Science Review/Revue internationale de science politique 19 (1):55-67.

Pennings, Paul. 1998. "The Triad of Party System Change: Votes, Office, and Policy." In Comparing Party System Change, ed. P. Pennings and J. C. Lane. London: Routledge.

Peterson, Susan, Michael J Tierney, and Daniel Maliniak. 2005. "Teaching and Research Practices, Views on the Discipline, and Policy Attitudes of International Relations Faculty at US Colleges and Universities." Williamsburg, VA: Program on the Theory and Practice of International Relations, The Wendy and Emery Reves Center for International Studies College of William \& Mary.

Powell, G. B. 1982. Contemporary democracies: Participation, stability and violence. Cambridge: Harvard University Press.

Powell, G. Bingham. 2000. Elections as instruments of democracy: Majoritarian and proportional visions. New Haven: Yale University Press.

Ray, James Lee. 2000. "On the level (s): Does democracy correlate with peace?" What do we know about war:299-316.

Reiter, Dan, and Erik R Tillman. 2002. "Public, legislative, and executive constraints on the democratic initiation of conflict." Journal of Politics 64 (3):810-26.

Rosecrance, R. 1986. The rise of the trading state: Commerce and conquest in the modem world. New York: Free Press.

Rummel, R. J. 1979. Understanding Conflict and War, Vol. 4: War Power and Peace. Beverly Hills: Sage.

Russett, Bruce, and John R. Oneal. 2001. Triangulating Peace: Democracy, Interdependence, and International Organizations New York: W.W. Norton.

Schampel, J. H. 1993. "Change in Material Capabilities and the Onset of War - a Dyadic Approach." International Studies Quarterly 37 (4):395-408.

Schuck, Andreas R. T., Rens Vliegenthart, Hajo G. Boomgaarden, Matthijs Elenbaas, Rachid Azrout, Joost van Spanje, and Claes H. de Vreese. 2013. "Explaining Campaign News Coverage: How Medium, Time, and Context Explain Variation in the Media Framing of the 2009 European Parliamentary Elections." Journal of Political Marketing 12 (1):8-28.

Schuck, Andreas R. T., Georgios Xezonakis, Matthijs Elenbaas, Susan A. Banducci, and Claes H. de Vreese. 2011. "Party contestation and Europe on the news agenda: The 2009 European Parliamentary Elections." Electoral Studies 30 (1):41-52.

Schultz, K. A. 2001. Democracy and Coercive Diplomacy: Cambridge University Press.

Shi, Min, and Jakob Svensson. 2006. "Political budget cycles: Do they differ across countries and why?" Journal of public economics 90 (8):1367-89.

Singer, J. D. 1966. "Formal Alliances." Journal of Peace Research 1:1-32. . 1972. "Correlates of War Project - Interim Report and Rationale." World Politics 24 (2):243-70. 1987. "Reconstructing the Correlates of War Dataset on Material Capabilities of States, 1816-1985." International Interactions (14):115-32.

Singer, J. D., and M. Small. 1972. The Wages of War 1816-1965: A Statistical Handbook. New York: Wiley. 
Slantchev, B. L. 2006. "Politicians, the Media, and Domestic Audience Costs." International Studies Quarterly 50 (2):445-77.

Tammen, R. L. 2000. Power Transitions: Strategies for the 21st Century. New York: Seven Bridges Press.

Tavits, Margit. 2007. "Clarity of Responsibility and Corruption." American Journal of Political Science 51 (January):218-29.

The White House. 1996. "A National Security Strategy of Engagement and Enlargement." Washignton, DC.

RELOGIT: Rare Events Logistic Regression 1.1, Cambridge, MA.

Van Belle, D. A. 1997. "Press Freedom and the Democratic Peace." Journal of Peace Research 34 (4):405.

Van Belle, Douglas A. 2000. Press freedom and global politics: Greenwood Publishing Group.

White, D. M. 1950. "The Gatekeeper. A Case Study in the Selection of News." Journalism Quarterly 27 (4):383-90.

Wlezien, Christopher, and Stuart N. Soroka. 2012. "Political Institutions and the Opinion-Policy Link." West European Politics 35 (November):1407-32. 